\title{
Dry reforming of methane under an electro-catalytic bed: effect of electrical current and catalyst composition
}

\author{
M. Banville ${ }^{1}$, R. Labrecque ${ }^{2}$ \& J.-M. Lavoie ${ }^{1}$ \\ ${ }^{1}$ Département de Genie Chimique et de Genie Biotechnologique, \\ Université de Sherbrooke, Canada \\ ${ }^{2}$ Hydro Quebec, Laboratoire des Technologies de l'Énergie (LTE), \\ Canada
}

\begin{abstract}
Dry reforming of methane (DRM) has been investigated under an electronactivated catalytic bed in a thermo-electrical reactor. The main objective of this work was to investigate what the impact of the electrical current on the conversion of methane is. The combination of thermal and electrical energy allowed achieving higher conversions for both reactants at temperatures varying from $850-950^{\circ} \mathrm{C}$. The electrical current at the different temperatures investigated during this work affected the conversion of methane and a threshold was pinpointed for different temperatures. At this point, the conversion of methane increased exponentially with the current provided to the catalyst. Furthermore, in order to confirm the catalytic potential of steel wool, different grades of stainless steel were tested for the DRM as well, showing lower conversion in all cases, in comparison to the carbon steel wool.
\end{abstract}

Keywords: dry reforming, methane, electricity, stainless, carbon steel.

\section{Introduction}

Natural gas (NG) is actually one of the cheapest sources of energy available on the planet. The actual market price for NG is $4.00 \mathrm{USD} / \mathrm{GJ}$ [1] (August 2014) before delivery and it is used essentially for the production of heat and/or power. The annual world consumption of natural gas was estimated in 2012 to be 120,014 
billion cubic meters amongst which one of the largest consumers was the United States that used approximately $21.27 \%$ of this volumes [2].

Although it is widely used for combined heat and power production, NG can as well be used as a source of carbon for the production of liquid fuels dedicated to transportation. A very significant example of this reality is the Pearl GTL facility made by Shell in Qatar representing an investment of 18-19 billions USD which can produce $140 \mathrm{kbo} / \mathrm{d}$ of liquefied gas as well as $120 \mathrm{kbo} / \mathrm{d}$ of natural gas, liquids and ethane [3]. Other projects were also considered for the conversion of methane to diesel using Sasol technology through a joined venture between Shell and Sasol [4]. In the latter case, in order to be converted into synthetic fuel, natural gas has to be converted into syngas, a mixture of hydrogen and carbon monoxide. The latter acts as a building block for the production of advanced biofuels using different technology as the well-known Fischer-Tropsch process.

Technologies that allows conversion of alkanes and more specifically in this case methane to syngas are called reforming technologies. And for the production of synthesis gas, three technologies are generally considered:

1) Autothermal reforming of methane (ATR)

2) Steam methane reforming (SMR)

3) Dry reforming of methane (DRM)

ATR and SMR technologies are well known and have been adapted to industrial scales decades ago. Whilst the first relates on the utilisation of oxygen (Eqn. 1), the second uses steam as oxidizing agent (Eqn. 2).

$$
\begin{array}{rlrl}
\mathrm{CH}_{4}+\frac{1}{2} \mathrm{O}_{2} & =\mathrm{CO}+2 \mathrm{H}_{2} & \Delta H_{298 \mathrm{~K}} & =-38 \mathrm{~kJ} / \mathrm{mol} \\
\mathrm{CH}_{4}+\mathrm{H}_{2} \mathrm{O}=\mathrm{CO}+3 \mathrm{H}_{2} & \Delta H_{298 \mathrm{~K}}=+205 \mathrm{~kJ} / \mathrm{mol}
\end{array}
$$

Dry reforming of methane is a process in which methane interacts with carbon dioxide in order to produce syngas. The $\mathrm{H}_{2} / \mathrm{CO}$ ratio generated from the dry reforming process is 1, in opposition to the SMR (ratio of 3) and the ATR (ratio of 2). The general equation for the DRM reaction is shown Eqn. 3 below.

$$
\mathrm{CH}_{4}+\mathrm{CO}_{2}=2 \mathrm{CO}+2 \mathrm{H}_{2} \quad \Delta \mathrm{H}_{298 \mathrm{~K}}=+247 \mathrm{~kJ} / \mathrm{mol}
$$

Although the DRM reaction has the highest energy requirement and that it produces a synthesis gas that has to be adapted for synthesis (especially on alkanes), it could be very beneficial on the environmental point of view. Instead of using steam or oxygen as oxidizing agent, the process used $\mathrm{CO}_{2}$, which is a fairly cheap oxidant, especially for industries that produces large volumes of it (gasification, fermentation, biomethanation, cement, etc...). Combination of carbon dioxide to methane could as well be beneficial for sequestration of carbon dioxide and to valorize this controversial feedstock, especially if the syngas is used for the production of synfuels.

Our team have previously reported on the DRM reaction using an electronactivated steel wool catalytic bed that showed a lot of potential for the dry 
reforming of methane [5, 6]. Labrecque and Lavoie [5] showed that electricity had an impact on the overall dry reforming process although they were not able to determine if the electricity was solely creating "hot spots" in the system or if it was contribution to the overall chemistry of the reaction. When operating under water-saturated methane $\left(1.70 \times 10^{-4} \mathrm{~mol} / \mathrm{s}\right)$ and carbon dioxide $\left(5.46 \times 10^{-5} \mathrm{~mol} / \mathrm{s}\right)$, they were able to convert in both cases $95+\%$ of the reactant producing an average $\mathrm{H}_{2} / \mathrm{CO}$ ratio of 2 . The total power investment was in the range $400-440 \mathrm{~W}$ which is significantly superior to the energetic value of the methane entering the reactor although it provided insights on the potential of this reforming approach. Two years later, Banville et al. [6] reported on the impact of the feed ratio $\left(\mathrm{CH}_{4} / \mathrm{CO}_{2}\right)$ and temperature on the DRM reaction with a specific interest towards the interaction of methane and carbon dioxide with the steel wool. The authors showed how the concentration of carbon dioxide did impact the catalyst. Whilst low oxidizing ratio below one induced a rapid oxidation of the catalyst at $950^{\circ} \mathrm{C}$, increasing the ratio to 1 allowed maintaining the catalyst functional for a longer period. As well, using the same ratio at lower temperatures induced a rapid oxidation of the catalyst. Thus the conclusions that can be drawn from this work are that the DRM reaction using steel wool is functional in a very specific range of feed and temperature.

In this work will be reported the effect of electrical and thermal energy on the DRM reaction. Using a custom made quartz reactor located in a tubular oven where the catalyst was maintained using two electrodes, dry reforming of methane was tested at different temperatures in order to identify the threshold point where minimal electrical energy was required in order to achieve high conversions. As well, the catalytic effect of steel wool was compared to different kind of stainless steel in order to prove that steel wool had a chemical interaction with the reactant and did not only induce hot spots.

\section{Experimental}

\subsection{Dry reforming reaction}

A scheme of the experimental setup used for the DRM reaction is depicted in Figure 1 below. The reactor was heated using a tubular furnace with a constant flow of nitrogen up to the operating temperature. Once the operating temperature achieved, the reactive mixture $\left(\mathrm{CO}_{2}: \mathrm{CH}_{4}: \mathrm{N}_{2}\right)$ was injected in the reactor at a steady flow (using a Brooke model SLA 5850S; 1 SLPM mass flow controllers) of 1:1:0.1 $\mathrm{L} / \mathrm{min}$. As a result, the molar composition for the respective gases at the inlet was of $47.6 \%: 47.6 \%: 4.8 \%$ respectively. Working temperature was measured at the core of the reactor as well as at the gas input and output. Prior to the GC injections, the reactions were maintained at steady state (for a given flow rate and temperature) for $20 \mathrm{~min}$ after which four GC samples were typically run before the flow rate and/or temperature were changed. Post-operation, the oven was turned off and the reactor was allowed to cool under $\mathrm{N}_{2}$. 


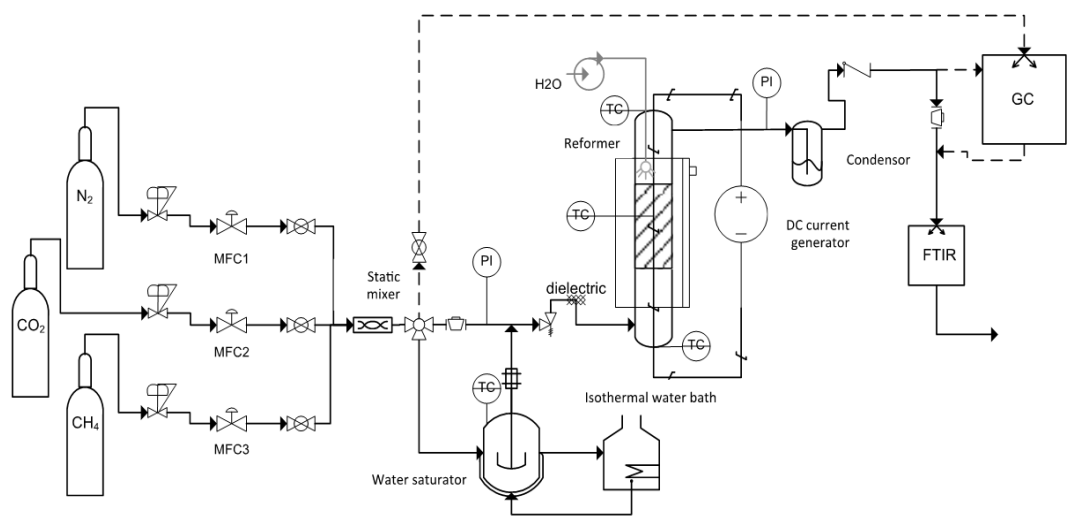

Figure 1: Process flow diagram for the electricity-induced dry reforming reactor.

The catalyst used for the experiments was a commercially available fine filament BullDog ${ }^{\odot}$ steel wool purchased from Canadian Tire ${ }^{\odot}$ hardware store in Sherbrooke, Quebec. Elemental analysis of the steel wool indicated that it was mostly composed of iron ( $98.5 \%$ ), with $0.24 \%$ carbon content, the rest being minor impurities. To validate the effect of the catalyst, tests were as well performed with stainless steel $(316 \mathrm{~L})$ wool. The gases used as reactant were purchased from Praxair including $\mathrm{CO}_{2}$ (98\% purity), $\mathrm{CH}_{4}$ (98\% purity) and $\mathrm{N}_{2}$ (99\% purity). Description of the reactor is presented elsewhere [5].

\subsection{Analytical}

Samples were analyzed online for the GC and in line with FTIR. The latter was a Varian 640-IR equipped with a PIKE technologies heated flow cell allowing quantification of $\mathrm{CO}_{2}, \mathrm{CH}_{4}, \mathrm{CO}$. The system was linked to the reactor using 1/4" piping and the system was located $2 \mathrm{~m}$ from the dry reforming reactor in line with the system. The inline configuration for the FTIR allows the total flow of the dry reforming reactor to pass through the $100 \mathrm{~mL}$ heated gas cell (PIKE technologies heated flow cell) at $120^{\circ} \mathrm{C}$ to reduce water condensation. Calibration of the FTIR system was performed with a mixture of gases bought from Praxair $\left(\mathrm{CO}_{2}, \mathrm{CH}_{4}\right.$ and $\mathrm{CO}$ ).

The chromatographic data were obtained using a Bruker 456 GC (TCD-TCDFID). The GC ran on three channels, the first channel was calibrated for the analysis of $\mathrm{H}_{2}, \mathrm{O}_{2}, \mathrm{~N}_{2}, \mathrm{CH}_{4}$ and $\mathrm{CO}$ using a thermal conductivity detector (TCD) for detection. Separation was achieved using a molseive 13 x 80/100 mesh $1.5 \mathrm{~m} \times 1 / 8$ " IS (BRP81071) and a Hayesep N 80/100 Mesh $0.5 \mathrm{~m}$ x 1/8" IS (BRP1480) column. The second channel was calibrated for the analysis of $\mathrm{CO}_{2}$, ethylene and acetylene, with separation achieved with dual Hayesep N 80/100 Mesh $0.5 \mathrm{~m} \times 1 / 8$ " IS (BRP1480) columns. The actual setup did not allow separation of ethane and ethylene and thus the response of the TCD for ethylene quantification includes ethane as well. The last channel of the $\mathrm{GC}$ was set up for the determination of the longer chain hydrocarbons $\left(C_{3}\right.$ to $\left.C_{12}\right)$ using a flame 
ionization detector (FID) and a BR-1 $10 \mathrm{~m}_{\mathrm{x}} 0.15 \mathrm{~mm}, 2 \mu \mathrm{m}$ (BR99150) column. The $\mathrm{GC}$ was calibrated using pure mixtures of gases $\left(\mathrm{CO}_{2}, \mathrm{CH}_{4}, \mathrm{CO}, \mathrm{N}_{2}, \mathrm{H}_{2}\right.$ and Propane) and allowed as well determination of other trace organics.

\section{Results}

In order to see the impact of the electricity on the whole system, blank test were performed using the first only the electrodes (made of stainless steel) and then the electrodes and the catalyst without any electrical power. The results from this experiment are shown in Figure 2 below.

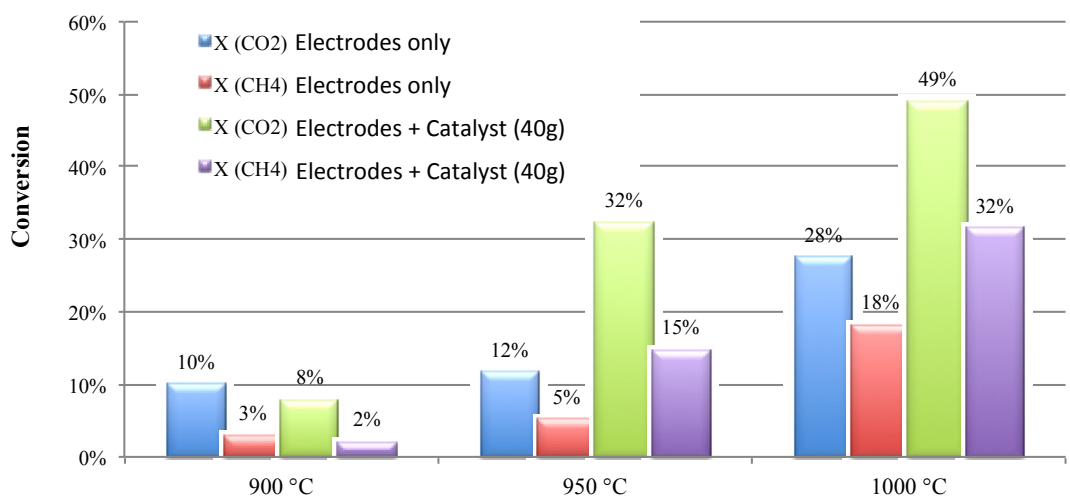

Figure 2: Effect of using electrodes (stainless steel) and the catalyst (Bulldog Steel wool) without any electrical input on the conversion of $\mathrm{CH}_{4}$ $(500 \mathrm{~mL} / \mathrm{min})$ and $\mathrm{CO}_{2}(500 \mathrm{~mL} / \mathrm{min})$ at temperatures ranging from $900^{\circ} \mathrm{C}$ to $1000^{\circ} \mathrm{C}$.

Figure 2 shows that both the electrodes and the catalyst had an impact on the conversion of $\mathrm{CH}_{4}$ and $\mathrm{CO}_{2}$. The impact of the catalyst did not seem to be as pronounced at lower temperatures since at $900^{\circ} \mathrm{C}$, conversion of methane with and without catalyst were comparable (2-3\%). Conversion of carbon dioxide in both cases is comparable as well (10 and $8 \%$ respectively). Increasing the operating temperature to $950^{\circ} \mathrm{C}$ shows a different pattern for methane conversion that goes from $5 \%$ when only in contact with the electrodes to $15 \%$ when $40 \mathrm{~g}$ of catalyst was added. As well the catalyst seemed to have an impact on the conversion of carbon dioxide that increased nearly as well by threefold. Increasing yet again the operating temperature to $1000^{\circ} \mathrm{C}$ showed as well an increase, going from 5 to $18 \%$ from $950^{\circ} \mathrm{C}$ to $1000^{\circ} \mathrm{C}$ when only the electrodes were in the reactor. At $1000^{\circ} \mathrm{C}$, utilisation of the catalyst led to an increase nearly by a twofold going from 18 to $32 \%$ for methane and from 28 to $49 \%$ for carbon dioxide. Since adding catalyst to the reactor does slightly reduce the residency time in the reactor, it thus provides proof of the impact of the steel wool as catalyst for the DRM reaction. Adding electricity to the system does provide a significant change in the conversion of methane as depicted in Figure 3 below. 


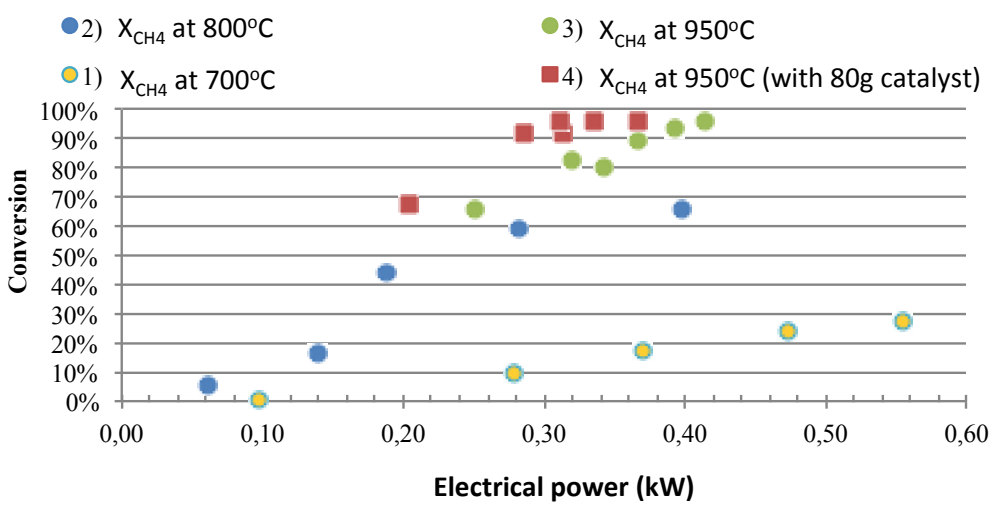

Figure 3: Combined effect of thermal and electrical energy on the DRM reaction on the conversion of $\mathrm{CH}_{4}$ using a $1.1 \mathrm{~L} / \mathrm{min}$ feed ratio with a 1:1 $\mathrm{CH}_{4}: \mathrm{CO}_{2}$ ratio at temperatures ranging from $900^{\circ} \mathrm{C}$ to $1000^{\circ} \mathrm{C}$ and electrical power of $0-600 \mathrm{~W}$ using $40 \mathrm{~g}$ of Bulldog ${ }^{\odot}$ steel wool as catalyst.

Results shows that electricity does promote dry reforming of methane and that the amount of electrical energy provided to attain high conversion is inversely proportional to the operating temperature of the oven. A conversion threshold can be observed in the results and especially for the results provided at $800^{\circ} \mathrm{C}$ where increasing the power from 150 to $200 \mathrm{~W}$ produced a leap of conversion from a little below $20 \%$ to nearly $50 \%$. Tests performed at $700^{\circ} \mathrm{C}$ showed an overall lower conversion even with the increasing electrical power.

DRM technologies are often constrained by deactivation of catalyst provoked by coking on the surface of the catalyst. Such tendency has been widely observed when classical steam reforming catalysts (as nickel supported on alumina) are operated for long periods under dry reforming conditions [7]. In the case of the electricity-induced dry reforming reactor presented in this work, our previous work shows that there is no carbon formation leading to catalyst deactivation as long as the operating conditions involves temperature above $850^{\circ} \mathrm{C}$ and $\mathrm{CH}_{4} / \mathrm{CO}_{2}$ ratio around 1 . Out of these parameters, the catalyst is oxidized although no coking is observed. However, in the stainless tubing in and out of the reactor carbon deposition was observed where temperature exceeded $500^{\circ} \mathrm{C}$.

Keeping in mind that the steel wool has a catalytic effect as well as an effect on the heat provided to the reaction via the possible occurrence of hotspots, it is important to estimate what is the total amount of energy invested in the system. One of the best approaches to do so and to compare as well to other reforming technology is to quantify the amount of total energy invested as compared to the calorific value of methane. As an example, operations at $950{ }^{\circ} \mathrm{C}$ combined with a $300 \mathrm{~W}$ electrical power input provided to the mixture more than $100 \%$ of its energetic value. Heating of methane from room temperature to operating conditions $\left(950^{\circ} \mathrm{C}\right)$ accounted for $8 \%$ of the calorific value of methane 
$(802.27 \mathrm{~kJ} / \mathrm{mol})$ while electrical power $(300 \mathrm{~W})$ that accounted for $111 \%$ of the calorific value of $\mathrm{CH}_{4}$. Combining both electrical and thermal input shows that the reaction under these conditions is hardly economical and the power investment is significantly higher that was is required for the DRM reaction $(247 \mathrm{~kJ} / \mathrm{mol}-30 \%$ of the energy value of methane). Reducing temperature to $800^{\circ} \mathrm{C}$, since it leads to lower conversion $(60 \%)$ raises the energy requirement to $177 \%$ of the calorific value of methane. In order to make this process more economical and potentially applicable to a scale up, significant power reduction must be considered and especially as far as the electricity investment is concerned. It is said that the high energy consumption of the reactor pertained to the intrinsic difficulties rising with a perfect thermal insulation for the small reactor $(230 \mathrm{cc}$ internal volume) that was used.

Since most of the research made on dry reforming aims at fixed bed catalyst, the best comparison for the electricity-induced conversion of methane would be plasma technologies. Amongst the technologies reported, the one that showed the best energy consumption was reported by $\mathrm{Li}$ et al. [7] who reported a $95 \%$ conversion of methane using a $1 \mathrm{~L} / \mathrm{min}$ feed of methane and 69 watts total. Since the system is not located in a tubular furnace, the electrical power is the only energy invested in the system. Overall, the energy consumption of this system was about $13 \%$ of the methane calorific value without any catalyst which may show that part of the energy may be provided by methane total oxidation or secondary interactions in the plasma [7].

In order to confirm the impact of steel wool on the reaction, other tests were performed using stainless steel 316L and results are presented in Figure 4 below.

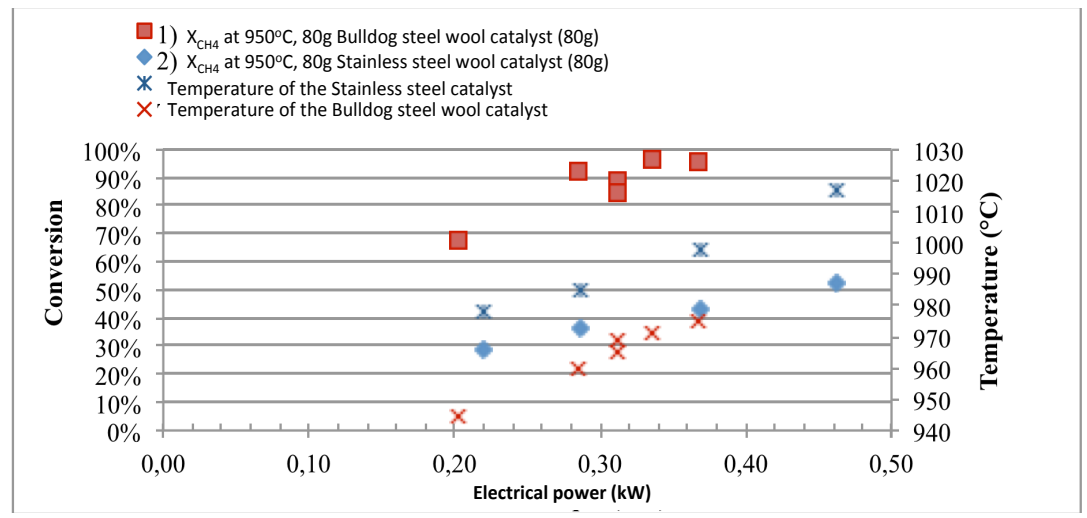

Figure 4: Effect of the catalyst (steel wool and stainless steel 326L wool) for methane reforming using a electricity-induced DRM reaction with a $1.1 \mathrm{~L} / \mathrm{min}$ feed ratio $\left(1: 1 \mathrm{CH}_{4}: \mathrm{CO}_{2}\right)$ at $950^{\circ} \mathrm{C}$ with an electrical power of $0-500 \mathrm{~W}$.

Results from Figure 4 shows that although it reached higher temperature, the stainless steel wool did not provide as high conversion as the Bulldog steel wool although the operating temperature of stainless was typically $15^{\circ} \mathrm{C}$ higher. 
Conversions using a $300 \mathrm{~W}$ electrical power input led to a conversion of approximately $30 \%$ of the methane under the stainless catalyst and higher than $90 \%$ for the Bulldog steel wool.

\section{Conclusions}

In this work, dry reforming of methane was performed using an electricity-induced reactor using carbon steel as catalyst. Results shows that the catalyst had a positive impact on the conversion of methane although combining electrical to thermal power generated the best results. Using a $300 \mathrm{~W}$ electrical input at $950^{\circ} \mathrm{C}$ and $80 \mathrm{~g}$ of catalyst allowed quasi-stoechiometric conversion of both methane and $\mathrm{CO}_{2}$. Modifying electricity whilst maintaining isotherm conditions showed that there was a threshold where conversions of methane increased by more than a twofold. The potential of the Bulldog steel wool was confirmed by comparing its effect on methane conversion with the one measured with stainless steel $(316 \mathrm{~L})$ showing significantly lower conversion under similar experimental conditions. At this point, the electricity-induced dry reforming process has potential although our experimental set up involved a higher specific energy consumption compared to actual reforming technologies. Adding steam to the system may show beneficial to reduce the electrical power consumption.

\section{Acknowledgements}

The authors would like to acknowledge participation of its industrial partners in funding this research project (CRB Innovations, Enerkem, Hydro Quebec (LTE)) as well as the funding agencies that supported this work (NSERC and CRIBIQ). As well the authors would like to thank the Industrial Chair on Cellulosic Ethanol and Biocommodities for its contribution via access to its analytical park.

\section{References}

[1] NASDAQ, U.S. National Average Natural Gas Price http://www.nasdaq.com/markets/natural-gas.aspx

[2] International Energy Statistics, Natural gas, consumption http://www.eia.gov/cfapps/ipdbproject/iedindex3.cfm?tid=3\&pid=26\&aid=2 \&cid=regions\&syid $=2011$ \&eyid $=2012$ \&unit $=$ BCF

[3] Shell, Pearl GTL - an overview, http://www.shell.com/global/aboutshell/major-projects-2/pearl/overview. $\underline{\mathrm{html}}$

[4] GTL in Focus: Sasol and Shell explore new markets, http://www.meed.com/supplements/2013/gas-to-liquids/gtl-in-focus-sasoland-shell-explore-new-markets/3186974.article 
[5] Labrecque, R. \& Lavoie, J. M. Dry reforming of methane with $\mathrm{CO} 2$ on an electron-activated iron catalytic bed. Bioresource technology, 102(24), pp. 11244-11248, 2011

[6] Banville, M., Lee, R. A., Labrecque, R., \& Lavoie, J. M. Interaction of $\mathrm{CO}_{2} / \mathrm{CH}_{4}$ with steel wool in an electrocatalytic dry reforming reactor. Energy and Sustainability IV, pp. 17-28, 2013

[7] Li, D., Li, X., Bai, M., Tao, X., Shang, S., Dai, X., \& Yin, Y. (2009). $\mathrm{CO}_{2}$ reforming of $\mathrm{CH} 4$ by atmospheric pressure glow discharge plasma: A high conversion ability. International Journal of Hydrogen Energy, 34(1), pp. 308-313, 2009. 